\title{
DENTAL MINERALIZATION AND SALIVARY ACTIVITY ARE REDUCED IN OFFSPRING OF SPONTANEOUSLY HYPERTENSIVE RATS (SHR)
}

\author{
A MINERALIZAÇÃO DENTAL E AATIVIDADE SALIVAR ESTÃO REDUZIDAS EM FILHOTES \\ DE RATAS ESPONTANEAMENTE HIPERTENSAS (SHR)
}

Gracieli Prado ELIAS', Otoniel Antonio Macedo dos SANTOS², Kikue Takebayashi SASSAKI ${ }^{3}$, Alberto Carlos Botazzo DELBEM ${ }^{4}$, Cristina ANTONIALI ${ }^{3}$

1- DDS,MSc, Post-graduate Student, Department of Pediatric Dentistry, UNESP - São Paulo State University, School of Dentistry of Araçatuba, SP, Brazil.

2- DDS, Undergraduate Student, Department of Basics Sciences, UNESP - São Paulo State University, School of Dentistry of Araçatuba, SP, Brazil. 3- MSc, PhD, Assistant Professor, Department of Basics Sciences, UNESP - São Paulo State University, School of Dentistry of Araçatuba, SP, Brazil. 4- DDS, MSc, PhD, Associate Professor, Department of Pediatric Dentistry, UNESP - São Paulo State University, School of Dentistry of Araçatuba, SP, Brazil.

Corresponding address: Cristina Antoniali - Faculdade de Odontologia de Araçatuba UNESP - Departamento de Ciências Básicas Rua José Bonifácio, 1193 Bairro: Vila Mendonça - Cep.: 16015-050, Araçatuba, SP, Brasil - Tel: +55 (18) 3636-3306; Fax: +55 (18) $3636-3332$ e-mail: crisant@foa.unesp.br

Received: July 28, 2005 - Modification: January 29, 2006 - Accepted: June 23, 2006

\begin{abstract}
S

Several pathologies have been diagnosed in children of hypertensive mothers; however, some studies that evaluated the alterations in their oral health are not conclusive. This study analyzed the salivary gland activity and dental mineralization of offsprings of spontaneously hypertensive rats (SHR). Thirty-day-old SHR males and Wistar rats were studied. The salivary flow was evaluated by injection of pilocarpine, the protein concentration and salivary amylase activity, by the Lowry method and kinetic method at $405 \mathrm{~nm}$, respectively. Enamel and dentin mineralization of the mandibular incisors was quantified with aid of the microhardness meter. The results were analyzed by the ANOVA or Student's t test $(\mathrm{p}<0.05)$. It was noticed that the salivary flow rate $(0.026 \mathrm{~mL} / \mathrm{min} / 100 \mathrm{~g} \pm 0.002)$ and salivary protein concentration $(2.26 \mathrm{mg} / \mathrm{mL} \pm 0.14)$ of SHR offspring were reduced compared to Wistar normotensive offspring $(0.036 \mathrm{~mL} / \mathrm{min} / 100 \mathrm{~g} \pm 0.003$ and $2.91 \mathrm{mg} / \mathrm{mL} \pm 0.27$, respectively), yet there was no alteration in amylase activity (SHR: $242.4 \mathrm{U} / \mathrm{mL} \pm 36.9$; Wistar: $163.8 \mathrm{U} / \mathrm{mL} \pm 14.1$ ). Microhardness was lower both in enamel $(255.8 \mathrm{KHN} \pm 2.6)$ and dentin $(59.9 \mathrm{KHN} \pm 0.8)$ for the SHR teeth compared to the Wistar teeth (enamel: $328.7 \mathrm{KHN} \pm 3.3$ and dentin: 67.1 KHN \pm 1.0 ). These results suggest that the SHR offspring are more susceptible to development of pathologies impairing oral health, once they presented lesser flow and salivary protein concentration and lower dental mineralization. Uniterms: Hypertension; Spontaneously hypertensive rat (SHR); Saliva; Tooth mineralization.
\end{abstract}

\section{RESUMO}

$D$

versas patologias têm sido diagnosticadas em filhos de mães hipertensas, entretanto alguns estudos que avaliaram as possíveis alterações na saúde oral não são conclusivos. Neste trabalho foram analisadas a atividade das glândulas salivares e a mineralização dental de filhotes de ratas espontaneamente hipertensas (SHR). Ratos machos, com 30 dias de vida, SHR e Wistar, foram estudados. O fluxo salivar foi avaliado pela injeção de pilocarpina e a concentração de proteínas e atividade da amilase na saliva, pelo método de Lowry e método cinético a $405 \mathrm{~nm}$, respectivamente. A mineralização do esmalte e dentina de incisivos inferiores foi quantificada através da medida da microdureza. Os resultados foram analisados pelo teste ANOVA ou t de Student's não pareado $(p<0,05)$. Verificou-se que o fluxo salivar $(0,026 \mathrm{~mL} / \mathrm{min} / 100 \mathrm{~g} \pm 0,002)$ e a concentração de proteínas na saliva $(2,26 \mathrm{mg} / \mathrm{mL} \pm 0,14)$ de filhotes SHR estavam reduzidos em comparação com filhotes normotensos Wistar (0,036 mL/min/100 g $\pm 0,003$ e 2,91 mg/mL \pm 0,27, respectivamente), porém sem nenhuma alteração da atividade da amilase (SHR: 242,4 U/mL $\pm 36,9$, Wistar: 163,8 U/mL $\pm 14,1$ ). A microdureza mostrou-se menor tanto no esmalte $(255,8 \mathrm{KHN} \pm 2,6)$ quanto na dentina $(59,9 \mathrm{KHN} \pm 0,8)$ dos dentes de SHR em comparação com os de Wistar (esmalte: 328,7 KHN $\pm 3,3$ e dentina: $67,1 \mathrm{KHN} \pm 1,0$ ). Estes resultados sugerem que filhotes SHR seriam mais susceptíveis ao desenvolvimento de patologias que prejudicam a saúde oral, uma vez que apresentaram fluxo e concentração proteica salivares reduzidos e menor mineralização dental. Unitermos: Hipertensão; Rato espontaneamente hipertenso (SHR); Saliva; Mineralização de dente. 


\section{INTRODUCTION}

Chronic maternal hypertension, as well as hypertensive disease of pregnancy, may significantly alter the fetal growth and well-being. The incidence of stillbirths, neonatal mortality and perinatal mortality is five times more frequent in pregnant women with chronic hypertension than in normotensive pregnant women ${ }^{24}$. Maternal mortality in the pregnancy-puerperium cycle secondary to hypertension is related to complications as eclampsia, brain hemorrhage, acute pulmonary edema, acute renal insufficiency and coagulopathies ${ }^{4}$.

Concerning the fetus and the newborn, several studies elucidate the complications that may occur because of maternal hypertension. Delayed intrauterine growth, oligohydramnios, premature birth and fetal suffering are common perinatal morbid disturbances. Neonatal morbidity is associated with a higher incidence of low birth weight and small newborns for the gestational age, in addition to frequent complications as hyaline membrane disease, polycythemia, leukopenia, hypoglycemia, infection and necrotizing enterocolitis ${ }^{1}$. There may also be pathologies associated with calcium and magnesium disturbances and hormones related to maintenance of serum and tissue concentrations of these minerals, as parathormone (PTH) and calcitonin, in neonatal and newborns of hypertensive mothers ${ }^{13}$. Associated with calcium disturbances, there might be alterations in bone and dental formation in these children; however, few studies so far have evaluated the possible alterations and its effects on the oral health of children of hypertensive mothers.

Increased prevalence of opaque and hypoplastic enamel resulting from impaired tooth development in utero has been attributed to intrauterine under nutrition, hypoxia, deprivation of calcium and phosphate, was well as fluoride and vitamins A, C and D particularly from $12^{\text {th }}$ and $16^{\text {th }}$ gestational week when mineralization of primary central incisor begins ${ }^{11,26}$. Enamel alterations in animal have also been attributed to intrauterine under nutrition of vitamin $\mathrm{A}$, $\mathrm{D}$ and calcium ${ }^{16}$. A reduced saliva secretion rate has been observed in rats after prolonged protein deficiency starting in utero ${ }^{8}$.

Clinical and experimental investigations provided evidences for increased caries levels associated with enamel hypoplasia and salivary gland hypofuction, in children and rats with pre- and postnatal nutritional deficiencies ${ }^{22}$. While these indirect evidences suggest the association between caries of the deciduous dentition and adverse events during gestation like hypertension, this hypothesis is not supported by data demonstrated in a recent epidemiological study ${ }^{27}$.

Based in these not conclusive literature data, the objective of the present study was analyzed the enamel and dentin teeth microhardness and salivary gland function in thirty days aged, male spontaneously hypertensive rats (SHR). SHR is the experimental model most similar to human essential hypertension. As these animals develop hypertension spontaneously without exception at the age of 7-15 weeks ${ }^{30}$, possible observed alterations in SHR offsprings' oral tissues could result from chronic maternal hypertension.

\section{MATERIALS AND METHODS}

\section{Animals}

The Institutional Review Board on Animal Studies of FOA-UNESP approved this study (protocol n. 37/03). The experiments were conducted employing 30-day-old offsprings of spontaneously hypertensive (SHR) and normotensive Wistar rats. Male offsprings of female SHR and Wistar were evaluated for establishment of the oral parameters (saliva and dental mineralization). The pregnant and in lactation female rats, as well as their offsprings, were kept in controlled room temperature $\left(22-24^{\circ} \mathrm{C}\right)$, light cycle (12 h/light and $12 \mathrm{~h} /$ darkness, lights on 08:00 a.m.) receiving standard food and water "ad libitum".

The spontaneously hypertensive rat (SHR) was used in this experiment because it is the animal model with the most similar essential arterial hypertension compared to that observed in human beings. Laboratorial studies have indicated that the hemodynamic characteristics of these animals are very similar to those of human essential hypertension $^{30}$. These animals are born normotense with average PA around $112 \mathrm{mmHg}$ and develop spontaneously or with no apparent or predetermining cause, an increase in PA from the 8th week after birth, which can reach values near $200 \mathrm{mmHg}$ at 12 weeks of age $\mathrm{e}^{30}$.

\section{Establishment of physiological parameters Blood pressure}

The systolic blood pressure (SBP) of female rats was recorded during pregnancy and lactation, at predetermined periods (pregnancy: days $0,7,14,16,18,20$; lactation: days 7, 14, 21, 28), by indirect tail-cuff plethysmography (Plethysmograph Physiiograph ${ }^{\circledR}$ MK-III-S / NBS - Narco Bio-Systems / Houston, Texas, USA). Prior to the PA registration, the rats were warmed at $40^{\circ} \mathrm{C}$ for 10 minutes in a hot-house with controlled temperature, which made it possible to obtain pulsation through tail artery check. Next, the animals were placed in a respective device composed with resin and then pulsation was detected by making use of an electrosphygmomanometer and pneumatic pulse transducer.

The registrations were made in a specific laboratory where noises were controlled, once only the operator was present in the room, allowing a better control of the animals' stress. The room's luminosity was controlled in the same manner as in the bioterium, where the animals were being kept. The PA registrations were carried out in the morning, since the lowest stress levels in rats can be established through pilot studies, mainly SHR, in that period. The rats were not anesthetized for the procedure, once plethysmography is not an invasive method.

Female Wistar rats with SBP around $112 \mathrm{mmHg}$ and SHR with SBP equal or higher than $150 \mathrm{mmHg}$, in the zero day of pregnancy, were used ${ }^{30}$. 


\section{Weight of rats and offspring and number of offspring per breeding}

The weight gain during pregnancy and lactation was established by weighing the rats at predetermined periods (pregnancy: days $0,3,7,10,14,17,20$; lactation: days 7, 14, 21,28 ) and comparison between the normotensive and hypertensive groups. Comparison was also performed for the number of offspring per breeding and their weight at 30 days of age.

The rat offsprings were not weighed at the moment of birth due to SHR rats' peculiar characteristics. Especially as regards this strain, mothers show a tendency to mutilate their offsprings when the operator gets in touch with them in the first weeks of life.

\section{Establishment of oral parameters \\ Saliva collection and removal of teeth}

Thirty-day old male rats, after 12-hour fasting, were anesthetized with xylazine ( $25 \mathrm{mg} / \mathrm{kg}$ body weight, by intramuscular (IM) injection, Copazine ${ }^{\circledR}$, Coopers $/ 10 \mathrm{~mL}$ ) and ketamine ( $45 \mathrm{mg} / \mathrm{kg}$ BW, IM, Dopalen, Vetbrands/10mL). The salivary flow was stimulated by pilocarpine nitrate (Sigma, 5 $\mathrm{mg} / \mathrm{kg}$ BW, IP). Saliva collection was performed according to the method of Bernarde ${ }^{5}(1956)$. The animals were placed in an inclined bed and saliva was collected in flasks kept in ice, for 15 minutes after the first drop. The saliva volume was calculated by the difference in weight of full and empty flasks, considering the density of saliva as being equal to 1 $\mathrm{mg} / \mathrm{mL}$. After collection, the salivary glands were removed and weighed. The animals were killed by excess anesthesia, and the mandibular incisors were individually removed, so that only the teeth were removed from the dental arch, without concomitant removal of bone tissue. Thereafter, the teeth were embedded in acrylic resin for evaluation of dental microhardness.

\section{Salivary protein concentration and salivary amylase activity}

Immediately after the saliva was collected, the protein concentration in the saliva was determined by the method of Lowry ${ }^{18}(1951)$ and salivary amylase activity was measured by the kinetic method at $405 \mathrm{~nm}$, using 2-chloro-pnitrophenyl-a-D-maltotrioside (CNP-G3) as substrate (Kit Amilasa 405, Wiener lab., 2000 - Rosario, Argentina).

\section{Enamel and dentin mineralization}

The mandibular incisors were embedded in acrylic resin, and the specimens were ground and polished for microhardness analysis in longitudinal section (MHLS) using the microhardness meter SHIMADZU MICRO HARDNESS TESTER HMV-2,000 (Shimadzu Co.- KyotoJapan), with Knoop indenter (KHN) and a static load of 15 grams for 10 seconds, connected to the software for image analysis CAMS -WIN (New Age Industries, USA). Three sequences of indents were performed, being the former from $200 \mathrm{~mm}$ of the incisal edge and the others at $500 \mathrm{~mm}$ from each other. At each sequence, 3 indents were performed at 20, 40 and $60 \mathrm{~mm}$ from the external enamel surface. For the dentin, the same sequence was followed, and the 3 indents were achieved from the dentinoenamel junction.

The Knoop hardness value at each point was achieved from the following equation: $\mathrm{KHN}=14.228 \mathrm{~L} / \mathrm{d}^{2} \mathrm{Kg} / \mathrm{mm}^{2}$, where $\mathrm{L}$ and $\mathrm{d}$ represent the load applied $(\mathrm{Kg})$ and the length of the larger diagonal of indent (mm), respectively ${ }^{20}$.

\section{STATISTICALANALYSIS}

The results were analyzed with utilization of the graphic and statistic software Graph Pad Prism 3.0. Data were evaluated as to normality and homogeneity and expressed as means \pm SEM. The significant differences in the SBP and weight gain of rats were analyzed by one-way analysis of variance for multiple comparisons, followed by the Tukey test. Unpaired Student's t test one-tailed was used for comparisons of two independents samples and evaluation of the saliva, dental microhardness, offspring's weight and number of offsprings per breeding. The significance level adopted was $5 \%(\mathrm{p}<0.05)$.

\section{RESULTS}

\section{Physiological parameters of rats and offspring}

The spontaneously hypertensive female rats presented a mean value of blood pressure (BP) $(179 \mathrm{mmHg} \pm 3$ ) higher than observed in Wistar rats $(110 \mathrm{mmHg} \pm 2)$. During the days of pregnancy (0-20) and lactation (7-28), the BP values of SHR were always higher than those of Wistar rats; however, variations in the BP of these animals were observed at these periods (Figure 1). A significant reduction of BP was detected in SHR at days 16 (159 mmHg \pm 4), 18 (153

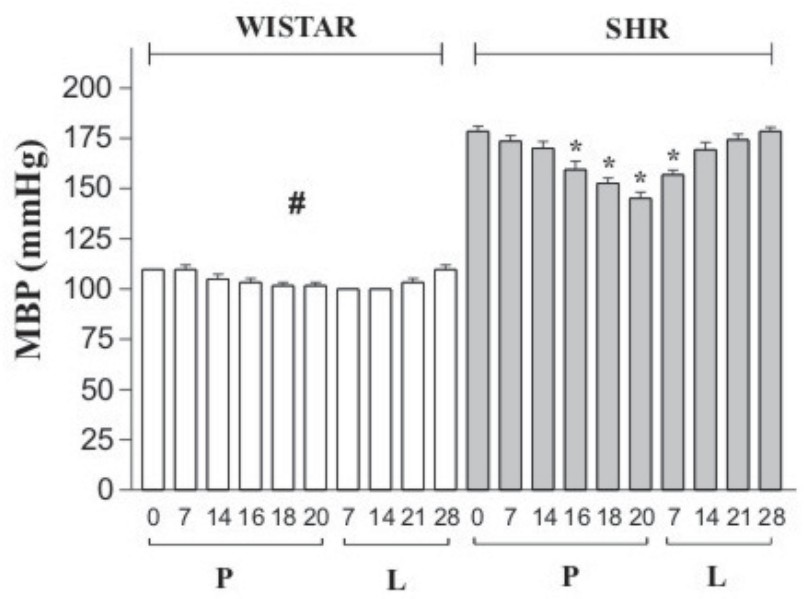

FIGURE 1- Mean blood pressure (MBP) of Wistar rats $(n=8)$ and SHR $(n=15)$ during the period of pregnancy $(P)$ and lactation (L). The bars represent the mean \pm SEM of the rats $\mathrm{BP}$ values measured on different days. * Significant difference $(p<0,05)$ between BP values of SHR in 0 day of pregnancy and others days of pregnancy and lactation. "significant difference between BP values of Wistar rats and SHR in every experiments performed $(p<0.01$ by ANOVA) 
$\mathrm{mmHg} \pm 3)$ and 20 (145 mmHg \pm 3 ) of pregnancy. However, the BP values measured in SHR at these days were higher $(\mathrm{p}<0.05)$ than the values measured in Wistar rats. In the group of Wistar rats, there was a tendency towards a reduction of BP associated with the end of pregnancy (102 $\mathrm{mmHg} \pm 2$, day 20). After the birth of the offspring, during lactation, the BP values of SHR rats were gradually increased. At the seventh day after birth, the BP of SHR was still reduced $(157 \mathrm{mmHg} \pm 2)$ when compared to the values measured on day zero, being reestablished at 14 days of lactation (169 $\mathrm{mmHg} \pm 4)$. At the end of the lactation period (day 28), the BP measured in SHR was similar to that measured on day zero of pregnancy.

The weight of female rats during pregnancy and lactation were compared between the groups of normotensive and hypertensive animals (Table 1 ). At day zero, SHR presented lower mean weight than the Wistar rats. During the entire period of pregnancy (days 0-21), the weight gain of Wistar rats $(100.1 \mathrm{~g} \pm 6.57)$ was larger than that of SHR (57.6 $\mathrm{g} \pm$ 3.25), and the largest increases occurred at the last week (days 14-21) for both groups. After birth and with the onset of lactation, the weight of Wistar rats and SHR rats was reduced. The weights of Wistar rat and SHR returned to the values observed at onset of pregnancy after 28 days of lactation. A smaller number of offspring was born from SHR when compared to the Wistar rats (Table 1 ).

Despite the smaller breeding (Table 1), the SHR offsprings did not achieve similar weight gain as the offspring of Wistar rats (Figure 2). At 30 days of life, the weight of SHR offspring (38.6 $\mathrm{g} \pm 1.1$ ) was lower than the weight of Wistar rats (58.1 g 2.0).

\section{Oral parameters of the study groups}

There were no differences in the weight of submandibular glands (SHR: $0.29 \mathrm{~g} \pm 0.01$; Wistar: $0.30 \mathrm{~g} \pm 0.01$ ), parotid glands (SHR: $0.36 \mathrm{~g} \pm 0.02$; Wistar: $0.40 \mathrm{~g} \pm 0.03$ ) and sublingual glands (SHR: $0.074 \mathrm{~g} \pm 0.003$; Wistar: $0.066 \mathrm{~g} \pm$ 0.003) of hypertensive and normotensive offspring.

The stimulated salivary flow rate (Figure 3A) in SHR offspring $(0.026 \mathrm{~mL} / \mathrm{min} / 100 \mathrm{~g} \pm 0.002)$ was reduced $(\mathrm{p}<0.05)$ compared to the control group $(0.036 \mathrm{~mL} / \mathrm{min} / 100 \mathrm{~g} \pm 0.003)$. In some tests, measurement was not possible in SHR

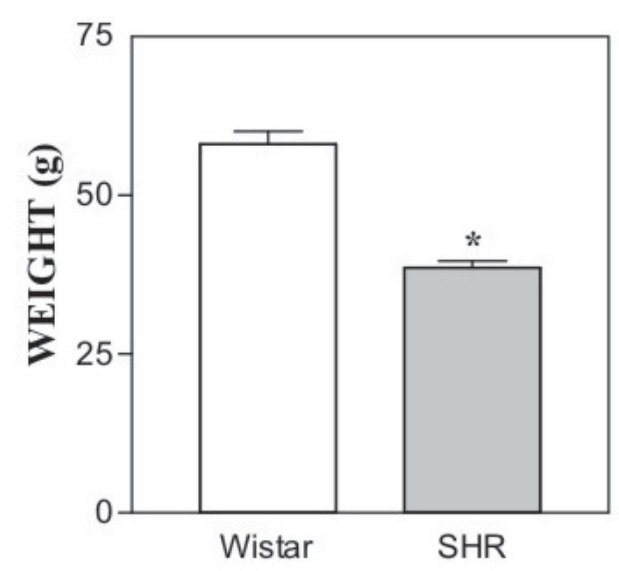

FIGURE 2- Weight of Wistar offspring and SHR offspring. The bars represent the mean \pm SEM of the weigh of Wistar offspring ( $n=74)$ and SHR offspring $(n=94)$ at 30 days after birth.

*Significant difference of weight between Wistar offspring and SHR offspring, at 30 days after birth $(p<0,05$ by unpaired t test between both groups)

TABLE 1- Weight gain of Wistar rats and SHR rats during the days of pregnancy and lactation and number of offspring per breeding

\begin{tabular}{|c|c|c|c|}
\hline \multirow[b]{2}{*}{ PERIOD } & \multirow[b]{2}{*}{ DAY } & \multicolumn{2}{|c|}{ WEIGHT OF RATS (g) } \\
\hline & & WISTAR $(n=8)$ & SHR (n=15) \\
\hline \multirow[t]{4}{*}{ Pregnancy $(\mathrm{P})$} & 0 & $247,5 \pm 7,3$ a,f,g & $201,2 \pm 4,1^{d}$ \\
\hline & 7 & $274,8 \pm 10,1^{\mathrm{a}, \mathrm{b}, \mathrm{g}}$ & $217,5 \pm 4,6^{\mathrm{d}, \mathrm{e}}$ \\
\hline & 14 & $293,9 \pm 10,2^{b}$ & $228,4 \pm 3,1^{e, f}$ \\
\hline & 21 & $347,6 \pm 11,1^{c}$ & $258,8 \pm 2,2^{g}$ \\
\hline \multirow[t]{4}{*}{ Lactation (L) } & 7 & $292,1 \pm 8,9^{A}$ & $213,1 \pm 3,1^{\mathrm{E}}$ \\
\hline & 14 & $289,0 \pm 9,8^{A}$ & $232,1 \pm 4,2^{\mathrm{D}, \mathrm{E}}$ \\
\hline & 21 & $278,0 \pm 9,7^{A, B}$ & $226,6 \pm 3,6^{\mathrm{D}, \mathrm{E}}$ \\
\hline & 28 & $252,3 \pm 7,6^{\mathrm{B}, \mathrm{D}}$ & $214,2 \pm 4,1^{\mathrm{E}}$ \\
\hline \multicolumn{2}{|c|}{ NUMBER OF OFFSPRING PER BREEDING } & $9,3 \pm 0,9$ & $6,3 \pm 0,6^{*}$ \\
\hline
\end{tabular}

The results are expressed as means \pm SEM. The different diminutive letters show significant differences during pregnancy period. The different capital letters show significant differences during lactation period.

* significant difference between Wistar and SHR groups ( $p<0,05$ by ANOVA) 
offspring, due to the small volume of saliva produced (experiments not included). The salivary protein concentration (Figure 3B) of Wistar offspring (2.91 mg/mL \pm $0.27)$ was significantly higher than that of SHR $(2.26 \mathrm{mg} / \mathrm{mL}$ \pm 0.14 ). The specific amylase activity (Figure 3C) in saliva (U/mL of saliva) was not different between SHR (242.4 U/ $\mathrm{mL} \pm$ 36.9) and Wistar (163.8 U/mL \pm 14.1$)$ offspring.

Microhardness analysis of the incisors teeth showed that enamel microhardness (Figure 4A) of SHR offspring $(255.8 \mathrm{KHN} \pm 2.6)$ was lower $(\mathrm{p}<0,05)$ than that of Wistar (328.7 KHN \pm 3.3 ). This alteration was also observed in dentin (Figure 4B) of SHR offspring teeth (59.9 KHN \pm 0.8 ), which have reduced hardness $(\mathrm{p}<0,05)$ when compared to teeth of Wistar offspring (67.1 KHN \pm 1.0$)$.

\section{DISCUSSION}

This study was the first to demonstrate that 30 days old male spontaneously hypertensive rat (SHR) present reduced dental mineralization and salivary gland activity when compared to Wistar rat at the same age. Besides the mechanisms involved in these alterations were not yet established, and more studies are necessary, the present findings suggest that these alterations would be secondary to the effect of maternal hypertension on the processes of new tissue formation during fetal and neonatal development.

In the present study, BP values higher than $150 \mathrm{mmHg}$ were measured in SHR female rats during pregnancy; however, a significant reduction of these values was observed between days 16 and 20 of this period. These results confirm other data from the literature, which associate the end of pregnancy of hypertensive and normotensive rats to physiological processes that reduce the peripheral vascular resistance ${ }^{7}$. Despite this reduction in $\mathrm{BP}$, hypertensive rats do not reach the normal blood pressure values observed in Wistar rats. Furthermore, the mean weight gain of female SHR during pregnancy and lactation were lower than observed for Wistar rats, the breeding of SHR was smaller, and the postpartum development of the SHR offspring did not follow the normal development of Wistar rats. These alterations could be associated to complications during pregnancy such hypertension. The lower weight of
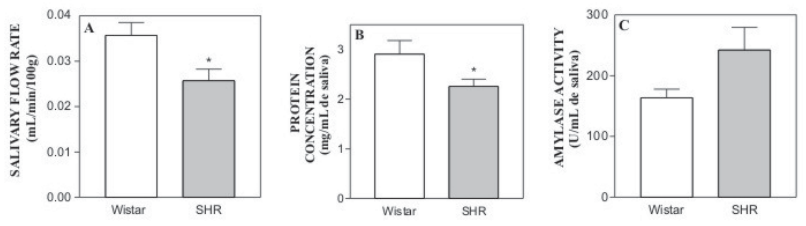

FIGURE 3- Salivary flow rate (A), salivary protein concentration (B) and salivary amylase activity (C) in the saliva of Wistar offspring $(n=8)$ and SHR offspring $(n=15)$. The bars represent the mean \pm SEM of salivary flow rate, salivary protein concentration and salivary amylase activity in the saliva of evaluated offspring.

*Significant difference of salivary flow and salivary protein concentration between Wistar offspring and SHR offspring ( $p<0,05$ by unpaired $t$ test between both groups) pregnant SHR rats would be directly associated to fetal development of offspring. As demonstrated previously, the fetal weight of SHR is lower than normotensive Wistar-Kyoto rats ${ }^{29}$ yet the weight of placenta remains unaltered. All these results corroborate with others suggesting that SHR is a model of intrauterine growth restriction that arises spontaneously without nutritional, surgical or endocrine intervention.

As observed in humans and animals, intrauterine growth restriction contributes significantly to perinatal morbidity and mortality as well as a predisposition to systemic diseases including hypertension and diabetes ${ }^{3}$, salivary gland hypofunction ${ }^{15}$ and increased prevalence of opaque and hypoplastic enamel ${ }^{21}$ latter in life.

Decreased saliva rate, decreased buffering capacity, and decreased salivary constituents, particular proteins, may define salivary gland hypofunction. Decrease in salivary secretion and alterations in the composition of saliva are often observed in individuals with type-1 diabetes mellitus and non-insulin-dependent ${ }^{19}$ and hypertensive ${ }^{10}$. Our results showed that SHR offsprings produce less saliva than offsprings of normotensive rats and the saliva has lower protein concentration. As no alteration was observed in amilase activity, more experiments were necessary to analyze the concentrations of others proteins like lyzozyme, lactoperoxidase and immunoglobulins. These alterations would not be related to the weight of parotid, submandibular and sublingual glands, since there was no difference in relative weight between the two groups. The reduced salivary function could be observed during SHR life, as it was also observed in young and adult $\mathrm{SHR}^{17}$. A reduction in density or sensitivity of muscarinic receptors in the salivary glands of these animals might contribute to such altered responses. On the other hand, an increase in the sensitivity of the b-adrenoceptor / adenylate cyclase receptor, which participates in the excretion of small amount of viscous saliva from sympathetic stimulation, was observed in young SHR (6-8 weeks) ${ }^{25}$.

In humans, hypertension has been considered a systemic condition that alters the dental formation, after observation that the crown diameter of deciduous and permanent teeth
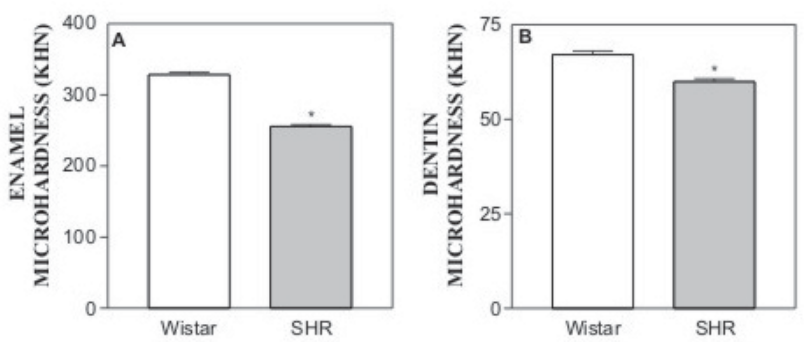

FIGURE 4- Microhardness of the mandibular incisors of Wistar and SHR offspring. The bars represent the mean \pm SEM of (A) enamel microhardness of Wistar offspring $(n=8)$ and SHR offspring $(n=15)$ and $(B)$ dentin microhardness of Wistar offspring and SHR offspring.

* significant difference of enamel microhardness and dentin microhardness between Wistar offspring and SHR offspring ( $p<0,05$ by unpaired $t$ test between both groups) 
would be reduced in children of hypertensive mothers ${ }^{12}$. Others complications ${ }^{27}$ during pregnancy such as diabetes, infection and nutritional deficiencies were also associated with problems in dental formation and hypoplastic enamel in children. These alterations could make these teeth more liable to develop carious lesions ${ }^{2}$. The results of the present study revealed that both enamel and dentin microhardness of mandibular incisors of SHR offsprings were lower compared to normotensive offsprings Wistar rats. The poor mineralization of these dental structures might favor the condition described as amelogenesis imperfecta observed in teeth of adults SHR-SP (stroke prone) rats ${ }^{14}$, due to the underdevelopment of dental ameloblasts, which are involved with the production, re-absortion and degradation of the enamel matrix and the transport of calcium for mineralization $^{23,28}$.

Clinical evidences and experimental studies have associated dental mineralization defects with variations in the serum calcium concentrations. It has been demonstrated that, in SHR, hypertension is followed by a reduction in ionized serum calcium homeostasis ${ }^{9}$. Hypocalcemia may occur because of lower active calcium transportation from mother to fetus through the placenta, several perinatal disturbances or alterations in serum parathormone (PTH) concentration $^{13}$. In SHR, it has been demonstrated that hypocalcemia leads to an increase in parathormone ${ }^{9}$. The mechanism involved in alteration of dental formation in SHR is not well explained, yet both hypocalcemia and the increase in PTH are directly involved with this alteration, since PTH receptors were found in odontoblasts, establishing the presence of hormonal control of odontogenesis through calcium transportation ${ }^{6}$.

Although the literature data are controversial and inconclusive $e^{22,27}$ the results of the present work reinforce the association between hypertension during pregnancy and buccal alterations, once the hypertensive (SHR) rats' offspring showed salivary hypofunction and dental hypomineralization. As these factors are a predisposition for caries development, specific studies on lesions (type/ size of lesion and development speed) should be conducted in SHR offsprings in order to evaluate a higher or lower susceptibility of these animals to caries.

\section{CONCLUSION}

In conclusion, the present findings indicated that SHR offspring have lesser salivary flow, salivary protein concentration and dental microhardness. These observed alterations can make the buccal environment more favorable to caries development, since this is a multifactorial disease related not only to bacterial and food factors, but also to host factors (tooth, saliva and its components). Further investigations should be carried out in order to determine the mechanisms involved in the observed salivary and dental alterations.

The obtained results suggest that mothers' blood hypertension is related to buccal alterations observed in their offspring, and that these alterations, on their part, may interfere with their oral health.

\section{ACKNOWLEDGMENTS}

To CAPES, from whom the first author has been recipient of a scholarship.

To PROINTER-PROPe-UNESP, for financial support to paper's publication (34/2005).

\section{REFERENCES}

1- Almeida JHCL. Aspectos perinatais das síndromes hipertensivas na gravidez. Rio de Janeiro; 1995. 151p. 1995. [Dissertação de Mestrado - Instituto Fernandes Figueira, Fiocruz].

2- Aoba T. Solubility properties of human tooth mineral and pathogenesis of dental caries. Oral Dis. 2004;10:249-57.

3- Barker DJP. In utero programming of chronic disease. Clin Sci. 1998;95:115-28.

4- Barrilleaux PS, Martin JNJr. Hypertension therapy during pregnancy. Clin Obstet Gynecol. 2002;45:22-34.

5- Bernarde MA, Fabian FW, Rosen S, Hoppert CA, Hunt HR. A method for collection of large quantities of rat saliva. J Dent Res. 1956;35:326-327.

6- Calvi LM, Shin HI, Knight MC, Weber JM, Young MF, Giovannetti A, et al. Constitutively active PTH/PTHrP receptor in odontoblasts alters odontoblast and ameloblast function and maturation. Mech Dev. 2004;121:397-408.

7- Coelho EB, Ballejo G, Salgado MC. Nitric oxide blunts sympathetic response of pregnant normotensive and hypertensive rat arteries. Hypertension. 1997;30(3Pt 2):585-8.

8- Deitchman GC, Antal M, Watson JG. Concentrations of immunoglobulin $\mathrm{G}$ and amylase in saliva of moderately protein undernourished rats. J Food Sci. 1980;45:1092-95.

9- DiPette DJ, Christenson W, Nickols MA, Nickols GA. Cardiovascular responsiveness to parathyroid hormone (PTH) and PTH-related protein in genetic hypertension. Endocrinology. 1992;130:2045-51.

10- Dodds MW, Yeh CK, Johnson DA. Salivary alterations in type 2 (non-insulin-dependent) diabetes mellitus and hypertension. Community Dent Oral Epidemiol. 2000;28:373-81.

11- Eastman DI. Dental outcomes of preterm infants. Newborn Infant Nurs Rev. 2003;3:93-98.

12- Garn SM, Osborne RH, McCabe KD. The effect of prenatal factors on crown dimensions. Am J Phys Anthropol. 1979;51:66578 .

13- Goshi LH, Ibidi SM. Distúrbios de cálcio e magnésio no período neonatal. In: Marcondes E. Pediatria básica. 8 ed. São Paulo: Servier; 1994. p.408-11.

14- Ishibashi K, Iino T, Sekiguchi F. Amelogenesis imperfecta, a new dental mutation in rats. Lab Anim Science. 1990;40:16-20. 
15- Johansson I, Ericson T, Bowen W, Cole M. The effect of malnutrition on caries development and saliva composition in the rat. J Dent Res. 1985;64:37-43.

16- Jontell M, Linde A. Nutritonal aspects on tooth formation. World Rev Nutr Diet. 1986;48:114-36.

17- Kraly FS, Coogan LA, Specht SM, Trattner MS, Zayfert C, Cohen A, et al. Disordered drinking in developing spontaneously hypertensive rats. Am J Physiol. 1985;248:R464-70.

18- Lowry OH, Rosebrough NS, Farr AL, Randall RJ. Protein measurement with the Folin phenol reagent. J Biol Chem. $1951 ; 193: 275-82$.

19- Moore PA, Guggenheimer J, Etzel KR, Weyant RJ, Orchard T. Type 1 diabetes mellitus, xerostomia and salivary flow rates. Oral surg oral med oral pathol oral radiol endod. 2001;92:281-91.

20- Petty ER. Hardness testing. In: Bunshar RF. Measurement of mecanical properties: technics of metals research. New York: Interscience Publishers; 1971. p.157-221.

21- Pimlott JF, Hwley TP, Nikiforuk G, Fitzhardinge PM. Enamel defects in prematurely born, low birth-weight infants. Pediatr Dent. $1985 ; 7: 218-223$.

22- Psoter WJ, Reid BC, Katz RV. Malnutrition and dental caries: a review of the literature. Caries Res. 2005;39:441-47.

23- Sasaki T, Takagi M, Yanasawa T. Structure and function of secretory ameloblasts in enamel formation. Ciba Found Symp. 1997;205:32-46

24- Sass N, Moron AF, El Kadre D, Camano L, Almeida PAM. Contribuição ao estudo da gestação em portadoras de hipertensão arterial crônica. Rev Paul Med. 1990;108:261-6.

25- Schmid G, Geiger H, Bahner U, Heidland A. Glandular adenylate cyclase system in genetic hypertension: age-dependent response to catecholamines. Eur J Pharmacol. 1988;147:397-402.

26- Seow WK. Effects of preterm birth on oral growth and development. Aust Dent J. 1997;42(2):85-91.

27- Shulman JD. Is there an association between low birth weight and caries in the primary dentition? Caries Res. 2005;39:161-67.

28- Takano Y. Enamel mineralization and the role of ameloblasts in calcium transport. Connect Tissue Res. 1995;33(1-3):127-37.

29- Wlodek ME, Westcott KT, Ho PW, Serruto A, Di Nicolantonio R, Farrugia W, et al. Reduced fetal, placental and amniotic fluid $\mathrm{PTH}_{\mathrm{R}} \mathrm{P}$ in the growth-restricted spontaneously hypertensive rat. Am J Physiol Regul Integr Comp Physiol. 2000;279:R31-8.

30- Yamori Y, Swales JD. The spontaneously hypertensive rat. In Swales JD. Textbook of hypertension. Oxford: Blackwell Scientific Press; 1994. p.447-55. 